Exemplaria Classica

Journal of Classical Philology

$22,2018,129-137$

ISSN 1699-3225

\title{
A NEW EDITION OF VENANTIUS FORTUNATUS: THE ART OF TRANSLATION
}

Michael Roberts(ed., trans.), Venantius Fortunatus: Poems, Dumbarton Oaks medieval library, 46, Cambridge, MA-London: Harvard University Press, 2017, xx+910 pp., \$29.95, ISBN 978-0-674-97492-0.

The new edition by Roberts of the poems of the $6^{\text {th }}$ century Latin poet Venantius Fortunatus is doubly welcome: firstly, as representing the first complete translation into English of the latter's occasional poetry; secondly, as forming an invaluable companion-piece to Roberts' earlier The Humblest Sparrow. ${ }^{1}$ While it has become a commonplace to view Fortunatus as the link between late antique and medieval poetics, ${ }^{2}$ the recognition of his importance continues to grow in tandem with the critical re-evaluation of late antique aesthetics and the blurring of boundaries between late antiquity and early medieval. ${ }^{3}$ The appearance, therefore, of a comprehensive edition readily accessible to English-speaking readers is particularly timely.

Following in the tradition of the Loeb and I Tatti Libraries the Latin and English versions appear on facing pages. The spacing is generous with an attractive and easily readable type-face. As one would expect from Roberts and from the series as a whole, the thrust is scholarly but equally handled with a light touch. The stated brief of the series is to serve both "scholars" and "general readers" and this seems to be reflected in both layout and content. Textual and background notes are relegated to the back with the information being kept to a necessary minimum, leaving the texts and translations uncluttered. The bibliographies are helpful and readers are encouraged to consult other editions (p.xx), with Roberts disclaiming "for the most part" any intention of advancing scholarship or of supplying detailed historical background (p.xix).

In keeping with this the introduction provides a good general overview, sketching out Fortunatus' career and addressing issues of

${ }^{1}$ M. Roberts, The Humblest Sparrow: the poetry of Venantius Fortunatus, Ann Arbor 2009.

${ }^{2}$ For an overview, see M. Roberts, "Bringing up the rear: continuity and change in the Latin poetry of late antiquity”, in J. Papy, W. Verbaal and Y. Maes (eds.), Latinitas Perennis, volume 1: The Continuity of Latin Literature, Brill 2006, 141-67.

${ }^{3}$ See, for example, the recent collection of essays: S. McGill, J. Pucci (eds.), Classics Renewed: Reception and Innovation in the Latin Poetry of Late Antiquity, Heidelberg 2016. 
addressees and publication. Fortunatus himself is situated effectively in relation to his literary predecessors, both classical and Christian. At the same time Roberts briefly reprises his earlier work to offer some stimulating observations on Fortunatus' use of metrication, in particular, the subdivision of the pentameter line reinforced by internal rhyme and accompanying sound-plays to provide "aural cues" for an audience "no longer sensitive to differences of quantity" (p.xiii). There are tantalising glimpses of current topics of literary critical debate, such as performance theory (Fortunatus' adoption of a female persona, p.xii) and metapoetics (his exploitation of the polysemous nature of the term sal, "salt", p.xvi), but these are not pursued.

Translation is a subjective skill involving interpretation and judgement. The difficulty is two-fold, the need to convey the underlying meaning (as perceived by the translator) while also conveying something of the original effect. Roberts demonstrates his awareness of this when he comments of Fortunatus' "verbal play" and "alliterative inventiveness" that they can present "challenges for the translator" (p.xiv). His aims, as carefully formulated in the introduction, to produce a "readable and accurate version" whilst avoiding "uncomfortable English" (p.xviii), seem eminently appropriate for a poet said to have a "flexible poetic style" and to have "forged a functional idiom" marked by its accessibility (p.xviii). What follows will focus on Roberts' translation of Fortunatus prose preface, comparing as appropriate to the translations of Reydellet ${ }^{4}$ and di Brazzano ${ }^{5}$, with a view to examining the challenges and choices faced by the translator. It will then offer a metapoetical reading of 6.8 which will be argued to offer a parallel with the preface.

The prose preface is an extremely elaborate piece of writing which in its complexity verges on the baroque. Not only is it the first piece of Fortunatus' writing with which the reader comes in contact, it also constructs a backdrop against which to read the rest of his work. It comprises a prefatory letter addressed to his patron Gregory, bishop of Tours, presented as being the catalyst for publication of the first collection, and consists of a (consciously) paradoxical fusion of display and humility, serving simultaneously as an apologia for his temerity in publishing and a challenge to his readers to appreciate his knowledge and skill. It can be divided loosely into three sections, the first praising the great intellects of the past, the second presenting Fortunatus himself, and the third in compliment to his patron. The challenges for the translator turn initially on the complexity of the syntax and Fortunatus' fondness for epigrammatic word-play. Into this, however, also comes the question of semantic patterning.

${ }^{4}$ M. Reydellet (ed.), Venance Fortunat, Poèmes, 3 vols., Paris 1994-2004. The preface is to be found in vol. 1, pp.2-6; 6.8 is in vol. 2, pp. 77-9.

${ }^{5}$ S. di Brazzano, Venanzio Fortunato Opere 1, Scrittori della Chiesa di Aquileia 8.1, Aquileia 2001. For the preface see pp. 88-93; for 6.8 see pp. 368-73. 
The first section comprises two very lengthy sentences, separated by three shorter linking ones which between them develop the initial premise, that great writing wins immortality, and at the same time pave the way for its corollary, that some writing is better left buried in obscurity. This, in turn, sets up Fortunatus' ironising self-presentation as an inferior poet in the second section. The first of these long sentences [1], extending over nine and a half lines of text, is essentially strung together with a series of parallel clauses and phrases, introduced by a relative clause (qui ... reliquere), picked up by a demonstrative (certe illi), and leading to a result clause (tale ... ut). Rather than dividing it into shorter blocks of sense, Roberts renders this as an admirably clear but nonetheless attractive piece of continuous English, which maintains the parallelism and effectively conveys both the sense and the feel of the original.

The sentence contains two epigrammatic flourishes. The first, epichirematibus coronati pariter et cothurnati, characterises the great intellects; the second, etsi non carne, vel carmine, forms the climax and encapsulates the paradoxical nature of their survival. In both cases, Roberts effectively maintains the epigrammatic effect without trying to replicate the word-play: "garlanded and elevated by tropes"; "if not in flesh then in verse". 7 Potentially more problematic is his handling of a passage a little further on [2]. The context is the cheating of Death, unable to abolish (quod) per ora viventium defunctos videt currere si non pede, poemate. Roberts' translation, "the sight of the dead still circulating on the tongues of the living, in poetry if not in person", raises several issues. While "circulating on the tongues" keeps the underlying sense of being read aloud, spoken about, it seems less forceful than "running through the mouths". So, too, the replacement of pede, "on foot" by the more anodyne "in person". ${ }^{8}$ More significantly, the substitutions disguise the fact that the phrase per ora seems to contain an allusion to the classical trope of the immortalised poet as flying/ floating (volitare) through the mouths/ on the lips (per ora) of men, ${ }^{9}$ while the juxtaposition in the original of currere with pede can be seen to draw on an old tradition of punning on physical and metrical feet. ${ }^{10}$

${ }^{6}$ Contrast Reydellet, who jettisons the associations of victory and the tragic stage and turns this into a noun phrase, "par la grandeur et la noblesse des tropes ... ".

7 Reydellet achieves some echo of the play: "sinon par la chair, du moins par le chant", while di Brazzano seems to throw away the epigrammatic effect: "anche se non corporalmente, per lo meno con la loro opera".

${ }^{8}$ Reydellet and in particular di Brazzano stay closer to the original: "de voir des défunts courir de bouche en bouche, sinon sur leurs pieds, du moins grâce à leurs poèmes"; "di vedere i defunti correre sulle bocche dei viventi, se non coi piedi, con la loro opera poetica”.

${ }^{9}$ The allusion, deriving from Ennius and borrowed by Virgil, is noted by Reydellet and di Brazzano.

${ }^{10}$ The tradition is noted by Reydellet. The phrasing may also point more specifically towards a playful contamination with the Horatian dismissal of Lucilian verse as incomposito 
The second of the two long sentences [3] works to nuance and qualify the notion of immortality. The assertion which precedes it is pivotal to the development of the argument and turns on a point of semantics. Death is doubly cheated, bis victam, if defeated sermone ... et mercede, rendered by Roberts as "by words and by renown". ${ }^{11}$ Fortunatus' pairing of sermone with mercede is perhaps more pointed than this rendition seems to suggest. While merces came to convey the concept of good will, favour, its initial associations belong to a more mercantile field of recompense and reward. It serves here to set up a linguistic nexus which turns on the concept of profit and loss: in the case of eloquence, failure to publish would have represented a loss, damnum pati; comprised an act of embezzlement, fecerant peculatum (so Roberts' "defrauded the public"). ${ }^{12}$ Immortality, being talked about, and merces, profit, in relation to the reader but perhaps also to the writer in the form of the acquisition of fame, favour, ${ }^{13}$ should go hand in hand. The syntax which follows, however, works to contradict the equation.

This second sentence opens accordingly with an emphatic sed and goes on to establish a contrast between two groups of writers, those whose works deserve recognition and those for whom fame would be notoriety: sed sicut hos/ ita ... eis. As attention shifts from the first to the second the syntax becomes looser but the sequence of thought is clearly indicated with the whole forming a continuous unit. In contrast to the earlier example Roberts has chosen to split this into four shorter sentences. This decision has several consequences. In the first place, the opening "but" seems to lose some of its force. Secondly, the continuity is partly undermined. Roberts' first two sentences maintain the opening contrast of the original, "(But) in the case of those"; "On the other hand in the case of those", although the formulation seems somewhat laboured. ${ }^{14}$ His rendition of the second part of Fortunatus' sentence, however, is more disconnected and creates the effect of discrete units. This is arguably compounded by the different treatment given to the opening subjunctives, "nec tantum sit ... ; minorisque dispendii ... videatur". In Roberts these become: "So it should not be ... "; "Let the

pede currere, "running with irregular foot" (Hor. Sat. 1.10.1).

${ }^{11}$ Roberts' translation echoes those of Reydellet, "par la parole et par la gloire" and di Brazzano, "dalla parola e dalla gloria".

${ }^{12}$ Conversely, the obscurity of lesser talent is described as minorisque dispendii, involving less loss, cost.

${ }^{13}$ The motif will be picked up ironically at the end in relation to Fortunatus himself, as he requests Gregory to repensurus, pay him back, recompense him, for his reluctant acquiescence by keeping his works out of general circulation.

${ }^{14}$ Reydellet and di Brazzano translate this as a single unit, with the latter staying closest to the Latin: "Mais si c'est"/ "en revanche"; "Ma come / così". Conversely, while Roberts maintains the anaphora, "(to) whom; "whose"; "who", it is modified by Reydellet and completely jettisoned by di Brazzano. 
loss be less ...". ${ }^{15}$ At the same time, his concluding "shame prevents notice being taken whereas ... a display of brazenness inflicts notoriety" neatly encapsulates Fortunatus' culminating opposition which pits pudor, shame, against audacia, shamelessness, notitia, fame, against nota, notoriety. ${ }^{16}$

The middle section [4][5], charting Fortunatus' journey from Ravenna to Metz, offers two instances of syntactic ambiguity. The first of these turns on (the absence of) critical judgement: $:^{17}$ quid inter haec extensa viatica consulte dici potuerit censor ipse mensura. Roberts reverses the order and treats the first part as an indirect question, "what ... could be properly expressed", dependent on an apostrophising imperative addressed to Gregory: "Judge for yourself ...". Reydellet and di Brazzano, on the other hand, present the first part as a direct question and take mensura in apposition to censor as supplying the response: the (only) critic was the "distance". ${ }^{18}$ Roberts' reading may find support from the fact that mensurare occurs as a verb in the final section [6]. ${ }^{19}$ On the other hand, the (re)-introduction of Gregory at this point in a context focusing rather on Fortunatus himself seems somewhat unexpected. ${ }^{20}$ At the same time, while Reydellet and di Brazzano's equation of "distance" with "critic" seems initially puzzling, it can be linked with extensa viatica, that is, a journey prolonged in time and space. While both readings in essence convey the same concept of ironic self-depreciation, the latter may better serve to underscore the potential for metapoetic and symbolic value, that is, the mental and spiritual distance travelled by Fortunatus. ${ }^{21}$

The second instance occurs in a similar context. In what follows, Fortunatus paints a hyperbolic and satirical picture of the drunken feasts of his uncultivated hosts. At the same time the satire spills over onto himself and his performance, the whole functioning as a justification of his unwillingness to publish. ${ }^{22}$ The conflation and confusion is reflected in a

${ }^{15}$ Reydellet and di Brazzano choose to dispense with the subjunctives altogether, treating them as two parallel statements of fact.

${ }^{16}$ quia illic obstat pudor ne prodatur notitia, hic audacia proditur ut ingerat notam (Pref. [3]).

${ }^{17}$ Judgement provides an important motif in what follows: non ... metus ex iudice; Baccho iudice (Pref. [5]).

${ }^{18}$ Reydellet, "La distance parcourue était mon censeur"; di Brazzano, "Proprio la distanza era il miglior critico".

${ }^{19}$ angusti sensus ingenium se mensuret censore ... (Pref. [6]), "a talent of limited capacity must evaluate itself ...". The continuation, quod est mittendum sub iudice, sets self-criticism against external judgement, that is, Gregory's.

20 Although Gregory was invoked as patron at the start of this section (Pref. [4]) some twelve lines have intervened.

21 That is, from urbanisation to wilderness, civilization to barbarism. Indeed, the sense of mensura as power, capacity, might be seen as an indication that the only valid criterion was the ability to compose at all.

${ }^{22} \mathrm{He}$ claims to have composed at the bidding of a Muse nescio gelida magis an ebria, in 
series of parallel oppositions which moves the focus from Fortunatus (mihi tantundem valebat), to his audience (apud quos nihil disparat), then to both together (ut inter illos egomet). By blurring the distinction, it leaves open the question of whether it is their judgement or his performance or both alike which are impaired. Between the two last comes a hanging phrase with no main verb but two present participles, sola saepe bombicans barbaros leudos arpa relidens, leaving it unclear whether instrument or poet is to be taken as the subject. In contradistinction to Reydellet and di Brazzano, ${ }^{23}$ Roberts seemingly opts for the latter: "often only on their harps strumming barbarian lays". ${ }^{24}$ At the same time his conflation of the two participles, losing the onomatopoeic effect of bombicans and dissociating it from arpa, loosely rendered as plural ablative, may miss a trick. It seems very possible that the "buzzing harp" designates Fortunatus himself in an echo of the "sounding brass" and "tinkling cymbal" of the New Testament, classical scholar among the barbarians, Christian among unregenerate pagans. ${ }^{25}$

Fortunatus' verbose and elaborate prose preface stands at the opposite end of the spectrum from his playful and performative 6.8. Starting with metaphorical shipwreck ${ }^{26}$ and featuring a comic encounter with a thieving cook, this occasional poem turns on the notion of a river journey, seemingly undertaken as part of the royal entourage. Pointing up the potential for self-irony, Roberts, like George, characterises the account as "rueful". ${ }^{27}$ At the same time his carefully nuanced statement that the cook "allegedly commandeered a boat from Fortunatus", ${ }^{28}$ together with the comment that

a state of frigidity or inebriation or perhaps both. On the negative effects of intoxication as a poetic topos in late antiquity see L. Mondin, "La poesia nel tempo della vendemmia: Ennodio, carm. II 67 = 188 V”, IFC 14, 2014-2015, 135-65.

${ }^{23}$ Both make arpa the subject, retaining the first participle as adjectival but turning the second into a main verb: Reydellet, "souvent, seule une harpe bourdonnante faisait retentir de barbares chansons"; di Brazzano, "Spesso soltanto un'arpa ronzante faceva risonare canti barbari”.

${ }^{24}$ The phrase is sandwiched between two self-denigrations, mihi tantundem valebat raucum gemere quod cantare and egomet ... non canerem sed garrirem (Pref. [5]).

${ }^{25}$ factus sum velut aes sonans aut cymbalum tinniens (I Cor. 13.1). Immediately prior to this, Fortunatus has applied to himself the Virgilian contrast between "shrieking goose" and "singing swan".

${ }_{26}$ Through allusion, vagus exul (6.8.5); naufragus hospes (6.8.6), Fortunatus identifies himself with the (epic and tragic) Polyneices and/ or the (romantic and ultimately successful) Apollonius of Tyre. The allusions are noted by George in her translation of the poem: J. George, Venantius Fortunatus: Personal and Political Poems, Translated Texts for Historians 23, Liverpool 1995, 53-4.

${ }^{27}$ For Roberts, of the "chapter of accidents Fortunatus suffered" (xv); for George, of a "disastrous journey" (J. George, Venantius Fortunatus: a Poet in Merovingian Gaul, New York 1992, 180).

${ }^{28}$ This seems to qualify George's assertion that "a cook had commandeered his boat and crew" (George, "Merovingian Gaul", 180). In fact, "commandeering" may itself represent a rationalisation of the original which rather invokes the notion of "theft": absenti nautas 
the cook is "very much a stock character" (p.xv), seems to point away from a strictly literal reading of the incident, although again this is not developed. In fact, the very idea of a journey, as seen in the prose preface, offers itself for metapoetic interpretation. The question has recently been raised in relation to 6.8 by Walz, who draws comparisons with the multi-layered iter Brundisinum, journey to Brundisium, of Horace. ${ }^{29}$ The discussion here will start from one specific issue of translation and offer a metapoetical reading of the central episode. From there it will broaden out to a brief consideration of the poem as a whole.

The phrase in question, rendered by Roberts as "the pen did not carry as much weight as the pan", is part of a double opposition: plus iuscella coci quam mea iura valent. I nec tantum codex quantum se caccabus effert (6.8.18-19). Straddling two couplets, this forms the culmination of Fortunatus' tirade against the cook. ${ }^{30}$ In essence, these lines make the same point but with the terms reversed: the cook's iuscella, broths, soups, are pitted against Fortunatus' iura, (legal) rights; the codex, book, law code, against the caccabus, cooking-pot. The substitution of book with "pen" is made presumably for comedic effect, ${ }^{31}$ but it can also be seen as weakening the connection with the lines which immediately precede and follow it. The first part of the opposition exploits an established word-play between the homonyms ius, sauce, and ius, law, made famous by the Ciceronian attack on Verres. ${ }^{32}$ The legalistic overtones had already started in the previous line with the accusation of serious injury, injustice, gravis est iniuria facti (6.8.17) and will carry through to the conclusion, that Fortunatus has been deprived of a rightful share in his own property, ut mea nec mihi sit participata rates (6.8.20).

The ramifications of the codex / caccabus opposition may reach further. The caccabus clearly stands in for the cook, whose face has already been characterised as caccabus alter, a second cooking-pot (6.8.12); equally, therefore, the codex may be read as standing in for Fortunatus, mounting his legal challenge over the missing boat. Making a sea voyage and cooking both have a long tradition of metapoetical association, that is, with the activity of

abstulit atque ratem (6.8.8).

${ }^{29}$ Hor. Sat. 1.5. See D. Walz, "Meus Flaccus: Venantius Fortunatus und Horaz", Jahrbuch für Internationale Germanistik 38.1, 2006, 129-43. At stake is the issue of patronage.

${ }^{30}$ The section as a whole is characterised by Roberts as "the closest Fortunatus comes to an invective" (p.xv).

${ }^{31}$ Roberts' change is noted in the back (p. 867). It may also be an attempt to avoid replicating George's "a book is not as grand as a bowl" (George, Personal and Political, 53). The legal associations are maintained by both Reydellet, "le code a moins d'effet que le faitout", and di Brazzano, "si fa valere il codice meno della pentola".

${ }^{32}$ Cicero's ius Verrinum represents a double play, on "law/ sauce" and "Verres/ boar", that is, the reduction of "Verrine law" to "pork gravy" (Cic. Verr. 121). The echo is noted by Reydellet and di Brazzano. 
writing poetry, the first having its origins in the epic tradition, ${ }^{33}$ the second in comedy. ${ }^{34}$ This opens up the possibility that codex and caccabus also represent two types of poetry: the one (Fortunatus'), steeped in classical learning, the other (the cook's), vernacular and vulgar; the one written, the other oral; the one civilized, the other barbarian. ${ }^{35}$ The verbal abuse heaped on the cook can be read as an example of flagitatio, a form of public shaming. ${ }^{36}$ But the joke is surely on Fortunatus himself, forced to abandon serious poetry and to adopt the arma (6.8.13), implements, weapons, of his opponent. ${ }^{37}$

The absence of the boat functions as a running motif through the rest of the poem, as Fortunatus is provided by friends with auxilium, help (6.8.21) and solacia, relief, consolation (6.8.37) in the form of substitute vessels of comically inadequate solidity and capacity. ${ }^{38}$ In this context the supplying of a boat may perhaps be read as the provision of an opportunity of composing and reciting his poetry under a beneficent patron, ${ }^{39}$ with the original theft standing for its opposite. ${ }^{40}$ The poem ends with the transmutation of shipwreck into rescue as Fortunatus is given a hospitable reception and bids farewell to his kindly host. ${ }^{41}$ Within itself the poem can be seen to stage an entertainment which disguises its learning and sophistication under a veneer of improvisation and immediacy. In terms of metapoetics, the poem as a whole may perhaps function at two levels: as a poem about the activity of

${ }^{33}$ On Fortunatus' use of the shipwreck motif in relation to his (epic) Vita Sancti Martini see M. Roberts, “Venantius Fortunatus' Life of Saint Martin”, Traditio 57.1, 2002, 129-87, 180.

${ }^{34}$ On the the comic cook as substitute or foil for the poet see E. Gowers, The Loaded Table: Representations of Food in Roman Literature, Oxford 1993, 50-108.

${ }_{35}$ The sooty blackness of the cook, corde niger, fumo pastus, fuligine tinctus (6.8.11) contrasts strongly with the brightness attributed to the ancients at the start of the preface, luculenta ... ingenia; praeclaris operibus (Pref. [1]), while the onomatopoeic clattering of caccabus recalls bombicans ... arpa (Pref. [5]), the buzzing harp, as discussed earlier.

${ }^{36}$ See F. Graf, "Satire in a ritual context", in K. Freudenburg (ed.), The Cambridge Companion to Roman Satire, Cambridge 2005, 192-223. The cook is objectified, turned into a surface to be scrawled over with charcoal, carbone notetur (6.8.15), a likeness to be painted in pitch, piceum referat turpis imago virum (6.8.16).

${ }^{37}$ frixuriae, cocumae, scafa, patella, tripes (6.8.14) are lined up and deployed to form a perfect pentameter.

${ }^{38}$ From Vilicus, gracilis linter, a slender tub, skiff, too frail to carry anyone else and in imminent danger of shipwreck (6.8.23-32); through the offices of Gogo, quamcumque ... ratem, any old boat, incapable of holding even his baggage (6.8.39-42).

${ }^{39} \mathrm{On}$ Vilicus and Gogo as early patrons see George, Personal and Political, 53-4.

${ }^{40}$ George argues that Fortunatus is "staking his claim to be a court poet with powerful patronage" (George, A Poet, 180-181); Walz, on the other hand, argues that the humour shows that he is already well-established at court (Walz, "Meus Flaccus", 139-40).

${ }^{41}$ His host, Pap(p)ulus, is said to have furnished him with iucundam ... proram, an agreeable prow (6.8.49). Walz suggests that rather than (another) boat this may refer punningly to the poet's well-fed stomach (Walz, "Meus Flaccus", 134). The name itself may play on Pappus, the stock figure of a gullible old man from Atellan farce. 
writing poetry and, retrospectively, as charting Fortunatus' early career as a Latin poet in Merovingian Gaul, a poetic variant to set alongside the journey of the preface.

The caveats raised above should in no way be seen as attempting to diminish the enormity of Roberts' undertaking or to detract from the very real solidity of his achievement. The intention has rather been to provoke debate and stimulate discussion by highlighting the value of consulting a range of interpretations. The readability and clarity of Roberts' translation provides an excellent jumping-off point for academics and general readers alike, with this edition both comprising an invaluable resource for the present and representing a milestone for future scholarship.

GILLIAN KNIGHT University of Reading g.r.knight@reading.ac.uk 
